\author{
О. Г. Мінченко \\ ORCID https://orcid.org/0000-0002-7093-5173 \\ Scopus Author ID 7005583749 \\ Д. О. Мінченко ${ }^{1,2}$ \\ ORCID https://orcid.org/0000-0003-3823-0787 \\ Scopus Author ID 55926952700 \\ М. М. Корда ${ }^{3}$ \\ ORCID https://orcid.org/0000-0002-6066-5165 \\ Scopus Author ID 6603826839
}

${ }^{1}$ Інститут біохімії імені О. В. Палладіна НАН України, Київ

${ }^{2}$ Національний медичний університет імені О. О. Богомольця, Київ

${ }^{3}$ Тернопільський національний медичний університет

імені І. Я. Горбачевського МОЗ Украӥни, Тернопіль

\title{
ОБІРУНТУВАННЯ НЕОБХІДНОСТІ ВИВЧЕННЯ МОЛЕКУЛЯРНОЇ БІОЛОГІЇ В МЕДИЧНИХ УНІВЕРСИТЕТАХ
}

\author{
O. H. Minchenko1 ${ }^{\text {, D. O. Minchenko' }}{ }^{1,2}$, M. M. Korda ${ }^{3}$ \\ ${ }^{1}$ O. Palladin Institute of Biochemistry of the NAS of Ukraine, Kyiv \\ ${ }^{2} \mathrm{O}$. Bohomolets National Medical University, Kyiv \\ ${ }^{3}$ I. Horbachevsky Ternopil National Medical University, Ternopil \\ RATIONALE OF THE NECESSITY OF THE MOLECULAR BIOLOGY \\ STUDY IN MEDICAL UNIVERSITIES
}

\begin{abstract}
Анотація. У медичних університетах більшості країн світу при підготовці лікарів сучасного міжнародного рівня є обов’язковим вивчення основ молекулярної біології для більш глибокого розуміння механізмів виникнення і розвитку патологічних процесів в організмі людини, а також для пошуку шляхів їх подолання, розробки нових стратегій створення високоефективних лікарських препаратів з високою специфічністю і без побічних ефектів. Це обумовлено перш за все тим, що регуляція основних метаболічних процесів як у нормі, так і за різноманітних патологій опосередковується репрограмуванням функціональної активності геному на рівні різних сигнальних систем клітини.

Таким чином, молекулярна біологія надає знання про молекулярно-генетичні основи підтримання гомеостазу і молекулярні механізми розвитку метаболічних порушень за різноманітних патологій, зокрема таких, як онкологічні, серцево-судинні, ендокринні та інші, а також вказує на можливі шляхи їх подолання, а тому детальне вивчення цієї науки має надзвичайно важливе значення для підготовки лікарів високої кваліфікації міжнародного рівня.
\end{abstract}

Ключові слова: молекулярна біологія; генно-залежне репрограмування метаболізму; вища медична освіта.

Abstract. In medical universities of most countries of the world, for the training of the modern international level doctors, it is mandatory to study the basics of Molecular Biology for a deeper understanding of the mechanisms of origin and development of pathological processes in the human body as well as to find ways to overcome them, develop new strategies for creating of drugs with higher efficiency and specificity without side effects. This is due primarily to the fact that the regulation of major metabolic processes both in health and various pathologies is mediated by reprogramming of genome functional activity at the level of different cell signaling systems.

Thus, Molecular Biology provides knowledge of the molecular-genetic basis of homeostasis and the molecular mechanisms of the development of metabolic dysregulations in various pathologies, such as oncology, cardiovascular, endocrine, and others, and indicates possible ways to overcome them and therefore a detailed study of this science is very important for the training of high-level doctors of international level.

Key words: molecular biology; gene-dependent metabolism reprogramming; higher medical education.

Вступ. За останні десятиліття досягнуті фантастичні успіхи у вивченні структурно-функціональної організації геному людини, а також у вияснен-

(с) О. Г. Мінченко, Д. О. Мінченко, М. М. Корда ні молекулярно-генетичних механізмів регуляції різних метаболічних процесів як у нормі, так і за різноманітних патологічних станів, які відкривають нові можливості для розуміння причин виникнення 
і розвитку захворювань та їх метаболічних і неметаболічних ускладнень, а також для профілактики і лікування.

Мета статті - обгрунтувати необхідність вивчення молекулярної біології в медичних університетах.

Теоретична частина. Численними дослідженнями встановлено, що геном людини містить інформацію для синтезу великої кількості різних за своїм розміром і функцією рибонуклеїнових кислот (РНК), які $\epsilon$ необхідними для створення апарату синтезу білків (рибосомні та транспортні РНК; рРНК та тРНК), РНК, які кодують синтез білків (матричні РНК; мРНК), у тому числі й рибосомних білків (протеїнів) та аміноацил-тРНК-синтетаз, а також численну групу великих і малих за розміром некодуючих РНК, які відіграють надзвичайно важливу роль у регуляції експресії генів (рівня мРНК та протеїнів). До некодуючих РНК відносяться великі некодуючі РHK (внкPHK; IncRNA), малі ядерні PHK (мяРНK; snRNA), циркулярні PHK (circRNA) та мікроРНК (міРHK; miRNA), причому кількість цих РНК вимірюється десятками тисяч видів.

Вивчення структури і функції рРНК, тРНК та мРНК, що кодують рибосомні протеїни,
аміноацил-тРНК-синтетази й ряд інших асоційованих з функцією рибосом протеїнів, а також мутацій у генах, що їх кодують, має надзвичайно важливе значення для розуміння молекулярних механізмів протеїнового синтезу в нормі та за різних патологій, у тому числі й механізмів чутливості та стійкості до антибіотиків, як і до ряду лікарських препаратів [33, 34, 41]. Невелика частина мРНК транслюється на рибосом, що не пов'язані з ендоплазматичним ретикулумом, але більша частина рибосом є прикріпленими до ендоплазматичного ретикулума ще не до кінця з'ясованими механізмами і переважна більшість протеїнів у клітині синтезується саме на таких рибосомах шляхом трансляції мРНК (рис. 1). Обумовлено це тим, що синтезовані на прикріплених рибосомах поліпептиди мають перейти до люмену ендоплазматичного ретикулума для подальшої їх посттрансляційної модифікації і формування третинної структури зрілого протеїну, причому тут же відбувається й чіткий контроль правильності створеної третинної структури, а неправильно згорнуті протеїни негайно знищуються спеціальною системою деградації ERAD [8, 34].

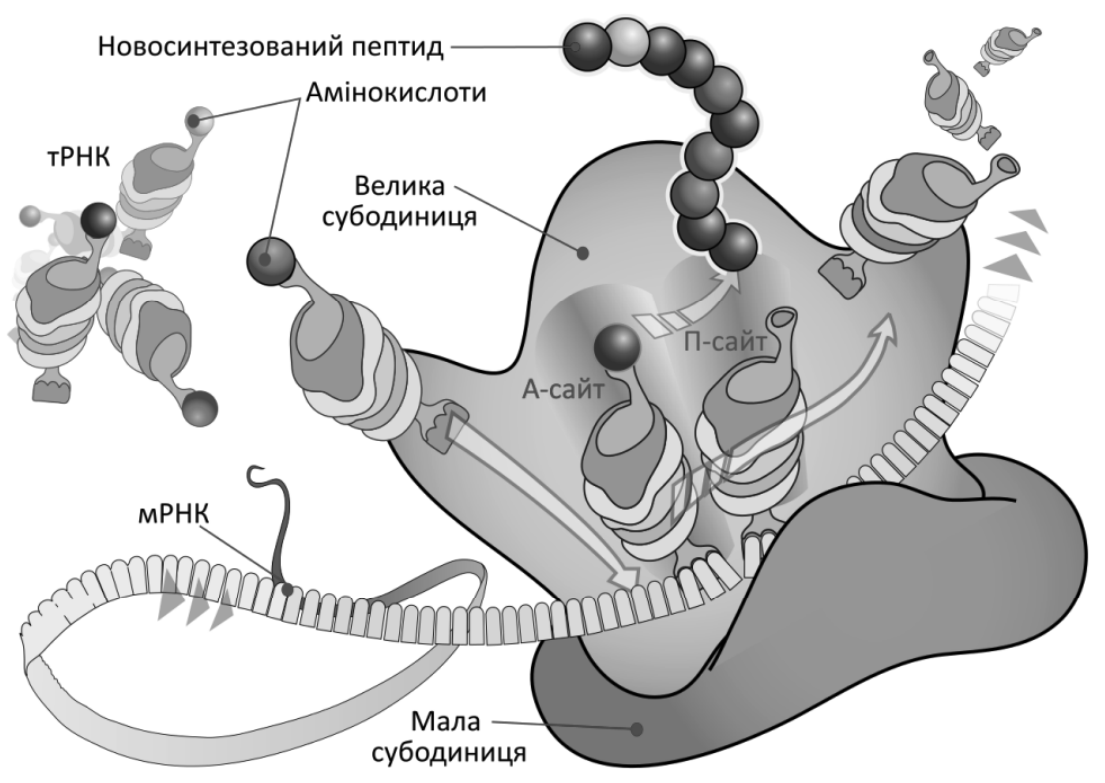

Рис. 1. Схематичне зображення рибосоми в процесі трансляції. Мала субодиниця зв’язує мРНК, а велика субодиниця направляє аміноацил-тРНК та пептидил-тРНК до матричної РНК, контролюючи правильне парування відповідних триплетів.

Роботи по вивченню структури і функцій рибосом й оригінальні структурні відкриття в області механізму роботи рибосом та синтезу протеїнів у живих клітинах були високо оцінені, і троє вчених Венкатраман Рамакрішнан, Томас Стейц і Ада Йо- нат були відзначені Нобелівською премією з хімії за 2009 р. Ці дослідження пролили світло на механізми дії антибіотиків, зокрема їх дії на функцію рибосом, а також на причини розвитку резистентності до них, були важливим кроком у процесі ви- 
вчення клінічної ефективності лікарської терапії і привели до раціонального конструювання нових антибіотиків.

Іншим важливим досягненням молекулярної біології і молекулярної медицини є відкриття і детальне вивчення ролі стресу ендоплазматичного ретикулума в нормі та за різноманітних патологій, як одного з найважливіших механізмів підтримання гомеостазу. За умов тривалого порушення умов гомеостазу внаслідок дії різноманітних чинників спостерігається накопичення в ендоплазматичному ретикулумі неправильно згорнутих протеїнів у результаті змін в активності ензимів, що контролюють посттрансляційну модифікацію протеїнів [8]. Саме цей стан і прийнято називати стресом ендоплазматичного ретикулума. За умов стресу активуються три сенсорно-сигнальні системи ендоплазматичного ретикулума (PERK, IRE1 та ATF6), які генерують і передають сигнали із ендоплазматичного ретикулума до цитоплазми, рибосом, мітохондрій та ядра, блокуючи синтез основної маси протеїнів і активуючи синтез лише тих протеїнів, що необхідні для виходу із стресового стану, знищення неправильно згорнутих протеїнів та відновлення гомеостазу [5, 8].

Стрес ендоплазматичного ретикулума є необхідним компонентом системи контролю біосинтезу інсуліну та ряду інших пептидних гормонів. Підвищений рівень глюкози є індуктором цього стресу в бета-клітинах, що призводить до пригнічення синтезу основної маси протеїнів і посиленого синтезу інсуліну відносно невеликою кількістю бета-клітин для всього організму та зниження рівня глюкози. А це є стоп-сигналом для синтезу інсуліну [7]. Разом 3 тим, стрес ендоплазматичного ретикулума $\epsilon$ важливим фактором розвитку і резистентності до інсуліну та метаболічних захворювань, а тому пізнання детальних молекулярних механізмів резистентності до інсуліну, як і до інших пептидних гормонів, зокрема до лептину, є надзвичайно важливим для профілактики й лікування метаболічних захворювань, у тому числі й діабету 2 типу, який невпинно прогресує у всьому світі [36, 37].

Абсолютно залежними від стресу ендоплазматичного ретикулума є злоякісні пухлини, для яких цей стрес $є$ необхідним фактором їх росту та виживання внаслідок репрограмування геному і виключення негативних впливів як цього стресу, так і гіпоксії. I заслуга в розшифровці цих механізмів належить молекулярним біологам, які зробили дуже багато відкриттів при вивченні структури, функції та ме- ханізмів регуляції експресії генів, у тому числі й за стресу ендоплазматичного ретикулума [3, 6, 22, 24, 31]. Саме цей стрес забезпечує злоякісним пухлинам експресію тих генів, які є відповідальними за ангіогенез, посилення процесів проліферації, метастазування та пригнічення апоптозу, виключення тумор-супресорних генів і контроль багатьох інших асоційованих із пухлинним ростом процесів, зокрема гіпоксії. Гіпоксія в злоякісних пухлинах переважно не абсолютна, а відносна, функціональна. В пухлинних клітинах генеруються сигнали, що обумовлюють знижену інтенсивність споживання кисню для активації гліколізу та проліферативних процесів, а можливо й деяких інших, зокрема репрограмування функції мітохондрій [6, 22, 31]. Більше того, саме поява стресу ендоплазматичного ретикулума в пухлинних клітинах обумовлює розвиток резистентності до хіміотерапії [3]. Все це вказує на складний процес репрограмування геному в злоякісних пухлинах, причому не лише тих генів, що кодують синтез онкогенів, пухлинних супресорів, протеїнкіназ і протеїнфосфатаз, протеаз та рибонуклеаз, а й некодуючих РНК, зокрема мікроРНК, циркулярних РНК і великих некодуючих РНК [24, 25]. Було також виявлено, що стрес ендоплазматичного ретикулума контролює роботу генів біологічного годинника добових ритмів (circadian clock) [32]. У пухлинних клітинах цей стрес ще не виясненими механізмами відключає його роботу від центрального, перепрограмує на «самостійну» роботу, що, можливо, значною мірою і забезпечує посилений ріст пухлинних клітин.

Ідентифікація генів, що кодують білкові компоненти біологічного годинника добових ритмів, та вияснення молекулярних механізмів його роботи через петлю негативного оберненого зв’язку транскрипції-трансляції є ще одним прикладом великих досягнень молекулярної біології і біохімії, що були відзначені також Нобелівською премією з фізіології або медицини в 2017 р.: нагороду отримали Джефрі Голл та Майкл Росбаш. Добовий біологічний годинник є «стражем» гомеостазу, оскільки контролює циклічний характер перебігу різноманітних процесів у клітинах, але у випадку «надзвичайних ситуацій», зокрема стресу ендоплазматичного ретикулума, «передає владу» в його руки, про що було вказано вище [32]. Відомо, що порушення біологічних ритмів може призводити до розвитку багатьох хвороб, зокрема метаболічних та онкологічних.

На основі молекулярно-біологічних даних про роль стресу ендоплазматичного ретикулума були 
розроблені нові стратегії пригнічення росту злоякісних пухлин шляхом інгібування одного із сенсорно-сигнальних шляхів стресу ендоплазматичного ретикулума, а саме IRE1 (від ендоплазматичного ретикулума до ядра 1), який має протеїнкіназну та ендорибонуклеазну активності і через які контролює експресію тисяч генів [2, 13, 19, 26, 27, 29]. На рисунку 2 представлено схематичне зображення цього сигнального шляху, який має протеїнкіназну та ендорибонуклеазну активності і через які контролює експресію генів різними механізмами для виходу із стресового стану, для відновлення гомеостазу.

Сенсорно-сигнальний ензим IRE1 контролює експресію великої кількості генів, які мають відношення до регуляції процесів метаболізму, проліферації,

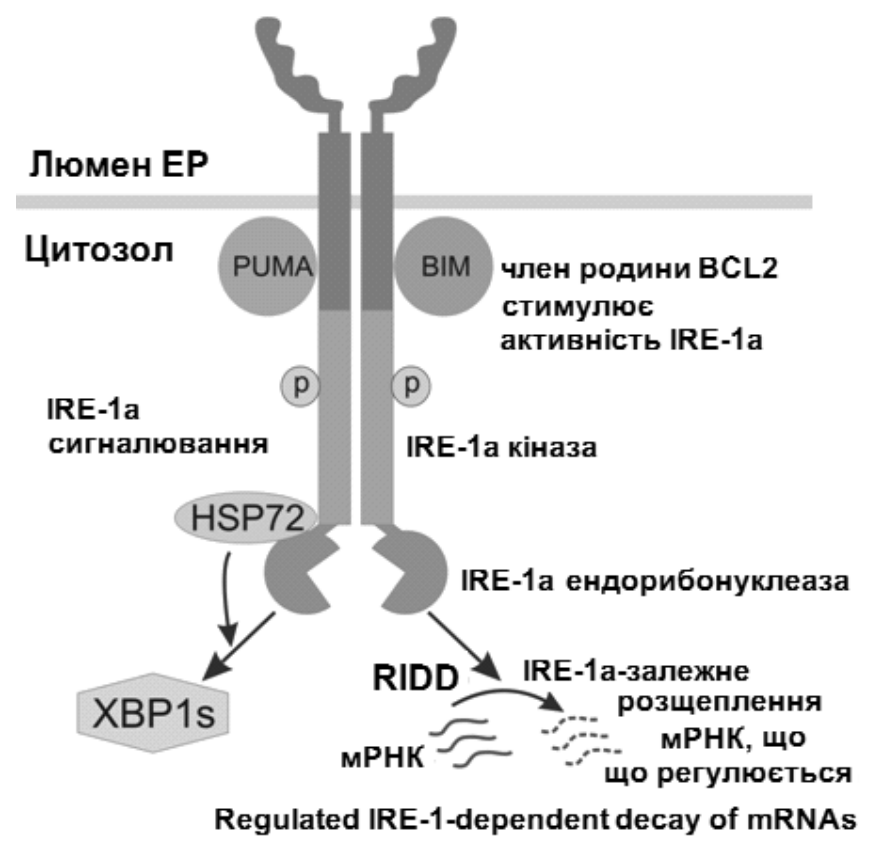

Рис. 2. Схематичне зображення сенсорно-сигнального шляху стресу ендоплазматичного ретикулума IRE1 (від ендоплазматичного ретикулума до ядра 1).

апоптозу та ангіогенезу. Він є обов'язковим компонентом злоякісного росту, а тому повне виключення функції IRE1 сигнального шляху в клітинах гліоми та аденокарциноми легень приводило до зменшення рівня експресії проангіогенних та пропроліферативних факторів, а також посилення експресії пухлино-супресорних та проапоптотичних факторів, що вносить суттєвий вклад у пригнічення росту пухлин із цих клітин $[2,19,29]$. Разом з тим, пригнічення лише ендорибонуклеазної активності сигнального ензиму IRE1 має значно більший протипухлинний ефект i, відповідно, інший характер змін в експресії ключових регуляторних факторів і ензимів, що контролюють процеси проліферації [13, 21, 26, 27]. Більше того, пригнічення ендорибонуклеазної активності IRE1 значно посилює чутливість до хіміотерапії [20]. Таким чином, пригнічення ендорибонуклеазної активності сигнального ензиму IRE1 $\epsilon$ важливим фактором пригнічення росту злоякісних пухлин, але такого роду протипухлинна дія має бути направлена лише на пухлинні клітини, оскільки в нормальних клітинах функціональна цілісність систем стресу ендоплазматичного ретикулума $\epsilon$ необхідною умовою збереження гомеостазу і здоров’я.

Важливим досягненням функціональної молекулярної біології та молекулярної медицини було вияснення молекулярно-генетичних механізмів відчуття клітинами кисню і включення механізмів подолання дефіциту кисню як за фізіологічних, так і патофізіологічних умов, зокрема в злоякісних пухлинах, при травмах, інфарктах та інсультах. Згідно з рішенням Нобелівського комітету, Нобелівською премією з фізіології або медицини 2019 р. нагороджені троє видатних вчених, які зробили найбільший внесок у вияснення молекулярних механізмів відповіді клітин на гіпоксію, що має велике практичне значення для медицини. Це Грег Семенза, Пітер Раткліфф та Вільям Кейлін. Г. Семенза виділив залежну від гіпоксії субодиницю транскрипційного фактора HIF, ідентифікував ген, що її кодує, і показав, разом з іншими вченими, ії̈ участь у реакції клітин на гіпоксію, а також можливе практичне значення цих досліджень $[11,17,18$, 
42]. Протеїн HIF є транскрипційним фактором, який трансактивує експресію генів, що кодують синтез протеїнів, задіяних у реакціях адаптації до гіпоксії, зокрема тих протеїнів, які контролюють метаболізм глюкози, васкуляризацію та проліферацію клітин [13, 17, 18, 21]. Вільям Кейлін продемонстрував, що протеїн VHL (Von Hippel-Lindau tumor suppressor protein) негативно причетний до прояву гіпоксичних реакцій [39]. Пітер Раткліфф продемонстрував, яким чином HIF1а поєднаний з VHL у механізмах реакції клітин на гіпоксію, дослідив роль пролілгідроксилаз HIF1a (PHD ензими) в цих процесах, показавши, що саме пролілгідроксилаза HIF1a є сенсором кисню, який активує ці ензими разом з іонами заліза [12, 16, 38, 40]. Описані вище відкриття цих трьох нобелівських лауреатів узагальнені на рисунку 3.

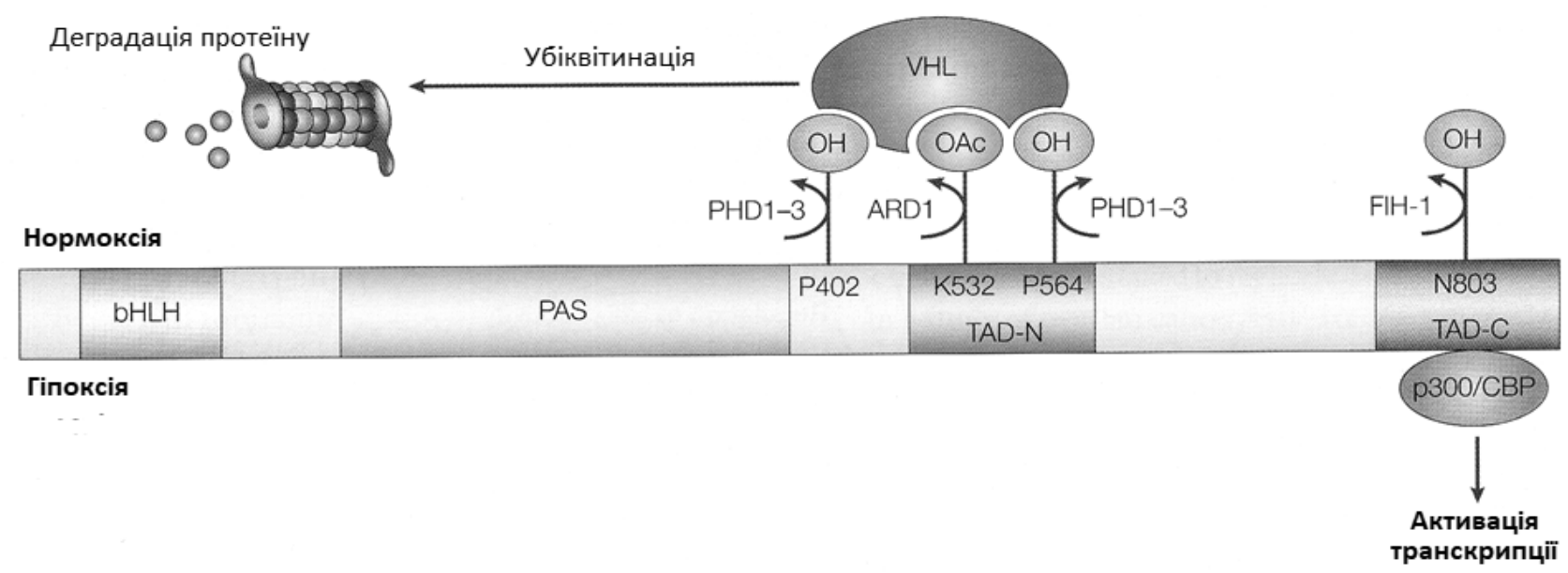

Рис. 3. Молекулярні механізми регуляції деградації HIF1а за нормального рівня кисню та за умов гіпоксії, а також активації транскрипційної його активності. Доменна структура молекули НIF1а: bHLH - basic helix-loop-helix; PAS - Per-ARNT-Sim; TAD-N - трансактиваційний домен N-кінця; TAD-C - трансактиваційний домен C-кінця.

За наявності кисню альфа-субодиниця HIF підлягає убіквітинації і протеасомній деградації, але для ініціації убіквітинації альфа-субодиниці HIF необхідні пролілгідроксилаза HIF1a та протеїн VHL, причому саме пролілгідроксилаза, як сенсор кисню і її активатор, вносить «чорні» мітки в альфа-субодиницю HIF. Відомо, що є три різних гени, які кодують різні за своїми властивостями альфа-субодиниці HIF. Пролілгідроксилази альфасубодиниці HIF активуються не лише киснем, а й іонами заліза, за відсутності яких цей ензим не проявляє активності навіть за умов наявності кисню. Як видно із рисунка 3, за наявності кисню PHD ензим гідрокислює пролінові залишки (P) в позиції 402 та 564 молекули HIF1a, але для цього потребує зв'язування з VHL, який є розпізнавальним компонентом Е3 убіквітин-протеїн лігази. Зв’язування VHL активується також ацетилуванням залишку лізину (K) 532 ARD1 ацетилтрансферазою. Убіквітинація HIF1а веде до його деградації 26S протеасомою. Важливо відмітити, що кисень також регулює взаємодію HIF1а з коактиваторами транскрипції. Так, залежне від кисню окислення залишку аспарагіну (N) 803 в HIF1а протеїном HIF1AN/FIH1 (фактор інгібуючий HIF-1) блокує зв’язування р300 і CBP з HIF1а і таким чином інгібує опосередковану транскрипційним фактором HIF транскрипцію генів.

Відкриття убіквітин-залежного протеолізу, тобто ролі убіквітину в клітинній системі деградації білків у протеосомах, Агароном Чехановером разом 3 Аврагамом Гершко та Ірвіном Роузом було також відзначено Нобелівською премією з хімії 2004 р.

Водночас за умов гіпоксії швидкість окислення проліну та аспарагіну в HIF1a різко знижується і VHL не може зв'язатися з ним та ініціювати убіквітинацію і деградацію. Разом з тим, фактори активації транскрипції р300 та СВР можуть зв’язуватися з HIF1a, оскільки аспарагін не гідрокислюваний, і таким чином відбувається активація транскрипції залежних від HIF1а генів. Ці результати дійсно мають велике практичне значення для медицини, оскільки чітко вказують на шляхи пригнічення росту злоякісних пухлин, відновлення постінфарктних та постінсультних тканин, а також лікування анемії та деяких інших патологій.

Розвиток молекулярно-біологічних досліджень сприяв також виясненню механізмів стійкості до антибіотиків і створенню нових, більш ефективних антибіотиків. Відомо, що такі важливі класи 
антибіотиків, як макроліди, тетрацикліни, аміноглікозиди та оксазолідинони, проявляють антибактеріальну дію, впливаючи на рибосомні субодиниці шляхом інгібування біосинтезу білка, взаємодіючи 3 центрами ініціації, елонгації та термінації трансляції, а це $є$ ефективним підходом для боротьби 3 бактеріальними інфекціями [35]. Так, тетрациклін перешкоджає утворенню комплексу тРНК з рибосомою, зупиняючи таким чином синтез протеїнів. Хлорамфенікол (левоміцетин) інгібує пептидилтрансферазу бактеріальних рибосом, а циклогексимід є інгібітором елонгації трансляції мРНК на цитоплазматичних 80S рибосомах. Генетичні дефекти рибосомних протеїнів та факторів біогенезу рибосом є летальними на ранніх ембріональних стадіях розвитку вищих організмів. Більше того, порушення системи як трансляції, так і біогенезу рибосом може призводити до онкотрансформації клітин.

Яскравим прикладом великого значення вивчення експресії генів для теорії і клініки є також дослідження ролі зниження і підвищення рівня експресії гемоксигенази-1 (HMOX-1) та її активності на широкий спектр біологічних систем, а також за судинних захворювань [14]. Так, надекспресія HMOX-1 і збільшення іï̈ активності призводить до високого рівня білірубіну, що вимагає клінічного застосування специфічних інгібіторів активності цього ензиму, а зниження експресії та активності HMOX-1 спостерігається за ожиріння. За цього стану відбувається активація оксидативного стресу шляхом збільшення рівня білірубіну, СО та зниження рівня гему, опосередковуючи протизапальні, антиапоптотичні та прооксидантні ефекти. Але надекспресія HMOX-1 за умов ожиріння призупиняє ці процеси.

Яскравим прикладом важливого значення досягнень функціональної молекулярної біології для сучасної медицини $є$ результати численних досліджень про молекулярно-генетичну основу виникнення і розвитку метаболічних захворювань та їх ускладнень, зокрема ожиріння, резистентності до інсуліну і діабету 2 типу [7, 10, 15, 23, 28, 36, 37]. За останні десятиліття по всьому світу значно виросла кількість людей з ожирінням, у тому числі й підлітків. Ожиріння та його метаболічні ускладнення є однією із найбільш важливих медичних і соціальних проблем сьогодення, оскільки вони значною мірою обумовлені як впливом факторів довкілля і порушенням біологічних ритмів, так і функцією генів, генетично детермінованою схильністю до цієї патології. Важливість проблеми ожи- ріння пов'язана не стільки зі збільшенням маси тіла, скільки з розвитком різноманітних ускладнень, зокрема резистентності до інсуліну та діабету 2 типу [1]. Останнім часом особливе значення у розвитку ожиріння у дітей приділяють структурі ліпідних компонентів грудного молока і молочних сумішей для немовлят, а також дисрегуляції біологічного годинника, що контролює більшість фізіологічних та метаболічних процесів в організмі, оскільки саме від цих чинників значною мірою залежить розвиток ожиріння в подальшому житті [9].

Дослідженнями, проведеними на молекулярному та клітинному рівнях (рис. 4), встановлено, що за ожиріння відбувається функціональна перебудова геному, змінюється експресія великої кількості генів, причому не лише в жировій тканині, і в інших органах та тканинах, зростає кількість адипокінів, а також порушується рівень регуляторних мікроРНК, у тому числі й у плазмі крові [4]. Більше того, показано, що харчові ліпіди i, зокрема, поліненасичені жирні кислоти є потужними регуляторами експресії
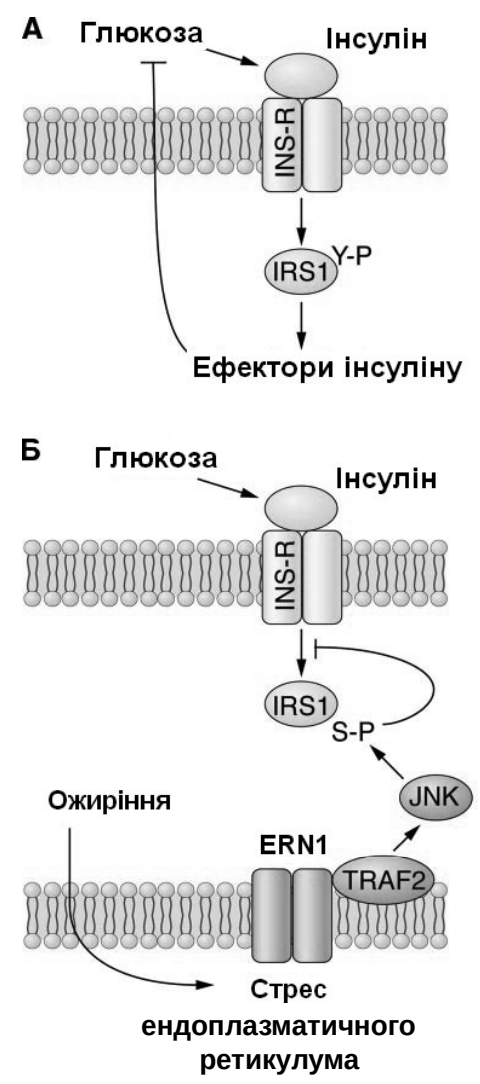

Рис. 4. Роль опосередкованого стресом ендоплазматичного ретикулума репрограмування геному в розвитку резистентності до інсуліну за умов ожиріння на рівні передачі сигналу від рецептора інсуліну

(INS-R) до його субстрату (IRS1): А - в нормі; Б - за умов ожиріння. 
генів, відповідальних за метаболізм ліпідів та глюкози, і забезпечують захист організму від розвитку резистентності до інсуліну, а також ожиріння [9].

Важливим досягненням молекулярної біології є вияснення молекулярних механізмів росту склеротичних бляшок через індукцію експресії генів VEGF, IL-8, COX2 та металопротеази ADAMTS1 за дії різних за структурою окиснених фосфоліпідів [30].

Висновки та перспективи подальших досліджень. Вивчення основ молекулярної біології при підготовці лікарів сучасного міжнародного рівня має бути обов'язковим для більш глибокого розуміння механізмів регуляції основних метаболічних процесів у нормі та причин виникнення і розвитку патологічних процесів в організмі людини, а

\section{Список літератури}

1. Altered clock gene expression in obese visceral adipose tissue is associated with metabolic syndrome / E. Vieira, E. G. Ruano, A. L. Figueroa [et al.] // PLoS One. - 2014. Vol. 9. - e111678.

2. A shift from an angiogenic to invasive phenotype induced in malignant glioma by inhibition of the unfolded protein response sensor IRE1 / G. Auf, A. Jabouille, S. Guerit [et al.] // Proc. Natl. Acad. Sci. U. S. A. - 2010. - Vol. 107. P. 15553-15558.

3. Avril T. Endoplasmic reticulum stress signaling and chemotherapy resistance in solid cancers / T. Avril, E. Vauléon, E. Chevet // Oncogenesis. - 2017. - Vol. 6 (8). - P. e373.

4. Changes in circulating microRNAs are associated with childhood obesity / A. Prats-Puig, F. J. Ortega, J. M. Mercader [et al.] // J. Clin. Endocrinol. Metab. - 2013. Vol. 98 (10). - P. E1655-1560.

5. Control of the unfolded protein response in health and disease / D. Doultsinos, T. Avril, S. Lhomond [et al.] // SLAS Discov. - 2017. - Vol. 22. - P. 787-800.

6. Endoplasmic reticulum proteostasis in glioblastomaFrom molecular mechanisms to therapeutic perspectives / J. Obacz, T. Avril, P. J. Le Reste [et al.] // Sci. Signal. 2017. - Vol. 10 (470). pii: al2323.

7. Endoplasmic reticulum stress and eIF2 $\alpha$ phosphorylation: The Achilles heel of pancreatic $\beta$ cells / M. Cnop, S. Toivonen, M. Igoillo-Esteve, P. Salpea // Mol. Metab. 2017. - Vol. 6. - P. 1024-1039.

8. Endoplasmic reticulum stress signalling - from basic mechanisms to clinical applications / A. Almanza, A. Carlesso, C. Chintha [et al.] // FEBS J. - 2019. - Vol. 286. P. 241-278.

9. Effect of dietary lipid structure in early postnatal life on mouse adipose tissue development and function in adulthood / A. Oosting, N. van Vlies, D. Kegler [et al.] // Br. J. Nutr. - 2014. - Vol. 111. - P. 215-226.

10. Fas and FasL expression in human adipose tissue is related to obesity, insulin resistance, and type 2 diabetes / також для пошуку шляхів їх подолання, розробки нових стратегій створення лікарських препаратів, які би діяли з високою ефективністю і без ускладнень. Це обумовлено перш за все тим, що регуляція основних метаболічних процесів як у нормі, так і за різноманітних патологій опосередковується репрограмуванням функціональної активності геному на рівні різних сигнальних систем клітин. Молекулярна біологія є підгрунтям для розуміння молекулярно-генетичних основ підтримання гомеостазу в організмі і молекулярних механізмів розвитку метаболічних порушень за різноманітних патологій, зокрема таких, як онкологічні, серцевосудинні, ендокринні та інші, а також чітко вказує на можливі шляхи їх подолання.

M. Blüher, N. Klöting, S. Wueest [et al.] // J. Clin. Endocrinol. Metab. - 2014. - Vol. 99. - P. E36-E44.

11. Giaccia A. HIF-1 as a target for drug development / A. Giaccia, B. G. Siim, R. S. Johnson// Nat. Rev. Drug Discov. - 2003. - Vol. 2. - P. 803-811.

12. HIFalpha targeted for VHL-mediated destruction by proline hydroxylation: implications for $\mathrm{O}_{2}$ sensing / M. Ivan, K. Kondo, H. Yang [et al.] // Science. - 2001. - Vol. 292. - P. 464-468.

13. High epiregulin expression in human U87 glioma cells relies on IRE1alpha and promotes autocrine growth through EGF receptor / G. Auf, A. Jabouille, M. Delugin [et al.] // BMC Cancer. - 2013. - Vol. 13. - P. 597.

14. HO-1 overexpression and underexpression: Clinical implications / G. S. Drummond, J. Baum, M. Greenberg [et al.] // Arch. Biochem. Biophys. - 2019. - Vol. 673. - P. 108073.

15. Hotamisligil G. S. Inflammation and endoplasmic reticulum stress in obesity and diabetes / G. S. Hotamisligil // Int. J. Obes. (Lond). - 2008. - Vol. 32, Suppl. 7. P. S52-S54.

16. Hypoxia inducible factor-alpha binding and ubiquitylation by the von Hippel-Lindau tumor suppressor protein / M. E. Cockman, N. Masson, D. R. Mole [et al.] // J. Biol. Chem. - 2000. - Vol. 275. - P. 25733-25741.

17. Hypoxia-inducible factor-1-mediated expression of the 6-phosphofructo-2-kinase/fructose-2,6-bisphosphatase-3 (PFKFB3) gene. Its possible role in the Warburg effect / A. G. Minchenko, I. Leshchinsky, I. Opentanova [et al.] // J. Biol. Chem. - 2002. - Vol. 277. - P. 6183-6187.

18. Hypoxic stimulation of vascular endothelial growth factor expression in vitro and in vivo / A. Minchenko, T. Bauer, S. Salceda, J. Caro // Laboratory Invest. - 1994. Vol. 71. - P. 374-379.

19. Inhibition of ERN1 modifies the hypoxic regulation of the expression of TP53-related genes in U87 glioma cells / D. O. Minchenko, S. V. Danilovskyi, I. V. Kryvdiuk [et al.] // Endoplasm. Reticul. Stress Dis. - 2014. - Vol. 1. - P. 18-26. 
20. Inhibition of IRE1 RNase activity modulates the tumor cell secretome and enhances response to chemotherapy / S. E. Logue, E. P. McGrath, P. Cleary [et al.] // Nat.Commun. - 2018. - Vol. 9 (1). - P. 3267.

21. Inhibition of the endoribonuclease of ERN1 signaling enzyme affects the expression of proliferation-related genes in U87 glioma cells / O. H. Minchenko, D. O. Tsymbal, M. Moenner [et al.] // Endoplasm. Reticul. Stress Dis. 2015. - Vol. 2 (1). - P. 18-29.

22. Integrated endoplasmic reticulum stress responses in cancer / M. Moenner, O. Pluquet, M. Bouchecareilh, E. Chevet // Cancer Res. - 2007. - Vol. 67. - P. 10631-10634.

23. Lee J. Unfolded protein response signaling and metabolic diseases / J. Lee, U. Ozcan // J. Biol. Chem. - 2014. Vol. 289. - P. 1203-1211.

24. Maurel M. Endoplasmic reticulum stress signaling: the microRNA connection / M. Maurel, E. Chevet // Am. J. Physiol. Cell. Physiol. - 2013. - Vol. 304. - P. C1117-C1126.

25. McMahon M. Regulation of the unfolded protein response by noncoding RNA / M. McMahon, A. Samali, E. Chevet // Am. J. Physiol. Cell. Physiol. - 2017. Vol. 313. - P. C243-C254.

26. Minchenko D. O. Dominant-negative constructs of inositol requiring enzyme-1alpha as an effective way to suppression of tumor growth through the inhibition of cell proliferation and angiogenesis and activation of apoptosis / D. O. Minchenko // J. Mod. Med. Chem. - 2015. - Vol. 3 (1). - P. 35-43.

27. Minchenko O. H. IRE-1alpha signaling as a key target for suppression of tumor growth / O. H. Minchenko, D. O. Tsymbal, D. O. Minchenko // Single Cell Biology. 2015. - Vol. 4 (3). - P. 118.

28. Mitogen-inducible gene 6 triggers apoptosis and exacerbates ER stress-induced $\beta$-cell death / Y. C. Chen, E. S. Colvin, B. F. Maier [et al.] // Mol. Endocrinol. - 2013. Vol. 27. - P. 162-171.

29. Molecular mechanisms of ERN1-mediated angiogenesis / O. H. Minchenko, K. I. Kubaichuk, D. O. Minchenko [et al.] // Int. J. Physiol. Pathophysiol. - 2014. - Vol. 5 (1). - P. 1-22.

30. Oxidized phospholipids stimulate angiogenesis via induction of VEGF, IL-8, COX-2 and ADAMTS-1 metalloprotease, implicating a novel role for lipid oxidation in progression and destabilization of atherosclerotic lesions / V. N. Bochkov, M. Philippova, O. Oskolkova [et al.] // Circ. Res. - 2006. - Vol. 99, No. 8. - P. 900-908.

\section{References}

1. Vieira, E., Ruano, E.G., Figueroa, A.L., Merino, B., Fernandez-Ruiz, R., Nadal, A., Burris, T.P., Gomis, R., et al. (2014). Altered clock gene expression in obese visceral adipose tissue is associated with metabolic syndrome. PLoS One, 9, e111678.

2. Auf, G., Jabouille, A., Guerit, S., Pineau, R., Delugin, M., Bouchecareilh, M., Favereaux, A., et al. (2010). A shift from an angiogenic to invasive phenotype induced in malignant
31. Papaioannou A. Driving cancer tumorigenesis and metastasis through UPR signaling / A. Papaioannou, E. Chevet // Curr. Top. Microbiol. Immunol. - 2018. - Vol. 414. P. 159-192.

32. Pluquet O. Watching the clock: endoplasmic reticulummediated control of circadian rhythms in cancer / O. Pluquet, N. Dejeans, E. Chevet // Ann. Med. - 2014. - Vol. 46 (4). - P. 233-243.

33. Protein synthesis by ribosomes with tethered subunits / C. Orelle, E. D. Carlson, T. Szal [et al.] // Nature. - 2015. - Vol. 6, 524. - P. 119-124.

34. Reid D. W. Diversity and selectivity in mRNA translation on the endoplasmic reticulum / D. W. Reid, C. V. Nicchitta // Nature Reviews Molecular Cell Biology. - 2015. Vol. 16. - P. 221-231.

35. Review on plant antimicrobials: a mechanistic viewpoint / B. Khameneh, M. Iranshahy, V. Soheili, B. S. Fazly Bazzaz // Antimicrob. Resist. Infect. Control. - 2019. - Vol. 8. - P. 118.

36. Scheuner D. The unfolded protein response: a pathway that links insulin demand with beta-cell failure and diabetes / D. Scheuner, R. J. Kaufman // Endocr. Rev. - 2008. Vol. 29. - P. 317-333.

37. Targeting endoplasmic reticulum stress in insulin resistance / L. Salvadó, X. Palomer, E. Barroso, M. VázquezCarrera // Trends Endocrinol. Metab. - 2015. - Vol. 26. P. 438-448.

38. The tumour suppressor protein VHL targets hypoxia-inducible factors for oxygen-dependent proteolysis / P. H. Maxwell, M. S. Wiesener, G. W. Chang [et al.] // Nature. - 1999. - Vol. 399. - P. 271-275.

39. Tumour suppression by the human von Hippel-Lindau gene product / O. Iliopoulos, A. Kibel, S. Gray, W.G. Jr. Kaelin // Nat. Med. - 1995. - Vol. 1. - P. 822-826.

40. Ubiquitination of hypoxia-inducible factor requires direct binding to the beta-domain of the von Hippel-Lindau protein / M. Ohh, C. W. Park, M. Ivan [et al.] // Nat. Cell Biol. - 2000. - Vol. 2. - P. 423-427.

41. Uechi T. A complete map of the human ribosomal protein genes: assignment of 80 genes to the cytogenetic map and implications for human disorders / T. Uechi, T. Tanaka, N. Kenmochi // Genomics. - 2001. - Vol. 72. - P. 223-230. 42. Wang G. L. General involvement of hypoxia-inducible factor 1 in transcriptional response to hypoxia / G. L. Wang, G. L. Semenza // Proc. Natl. Acad. Sci. U. S. A. - 1993. Vol. 90. - P. 4304-4308.

glioma by inhibition of the unfolded protein response sensor IRE1. Proc. Natl. Acad. Sci. U. S. A., 107, 15553-15558.

3. Avril, T., Vauléon, E., \& Chevet, E. (2017). Endoplasmic reticulum stress signaling and chemotherapy resistance in solid cancers. Oncogenesis, 6(8), e373.

4. Prats-Puig, A., Ortega, F.J., Mercader, J.M., MorenoNavarrete, J.M., Moreno, M., Bonet, N., Ricart, W., et al. (2013). Changes in circulating microRNAs are associated 
with childhood obesity. J. Clin. Endocrinol. Metab., 98 (10), E1655-60.

5. Doultsinos, D., Avril, T., Lhomond, S., Dejeans, N., Guédat, P., Chevet, E. (2017). Control of the unfolded protein response in health and disease. SLAS Discov., 22, 787-800.

6. Obacz, J., Avril, T., Le Reste, P.J., Urra, H., Quillien, V., Hetz, C., \& Chevet, E. (2017). Endoplasmic reticulum proteostasis in glioblastoma-From molecular mechanisms to therapeutic perspectives. Sci. Signal., 10 (470), pii: eaal2323.

7. Cnop, M., Toivonen, S., Igoillo-Esteve, M., \& Salpea, P. (2017). Endoplasmic reticulum stress and eIF2 $\alpha$ phosphorylation: The Achilles heel of pancreatic $\beta$ cells. Mol. Metab., 6, 1024-1039.

8. Almanza, A., Carlesso, A., Chintha, C., Creedican, S., Doultsinos, D., Leuzzi, B., Luís, A., et al. (2019). Endoplasmic reticulum stress signalling - from basic mechanisms to clinical applications. FEBS J., 286, 241-278.

9. Oosting, A., van Vlies, N., Kegler, D., Schipper, L., Abrahamse-Berkeveld, M., Ringler, S., Verkade, H.J. et al. (2014). Effect of dietary lipid structure in early postnatal life on mouse adipose tissue development and function in adulthood. Br. J. Nutr., 111, 215-226.

10. Blüher, M., Klöting, N., Wueest, S., Schoenle, E.J., Schön, M.R., Dietrich, A., Fasshauer, M., et al. (2014). Fas and FasL expression in human adipose tissue is related to obesity, insulin resistance, and type 2 diabetes. J. Clin. Endocrinol. Metab., 99, E36-E44.

11. Giaccia, A., Siim, B.G., \& Johnson, R.S. (2003). HIF1 as a target for drug development. Nat. Rev. Drug Discov., 2, 803-811.

12. Ivan, M., Kondo, K., Yang, H., Kim, W., Valiando, J., Ohh, M., Salic, A., Asara, J.M., Lane, W.S., \& Kaelin, W.G. Jr. (2001). HIFalpha targeted for VHL-mediated destruction by proline hydroxylation: implications for $\mathrm{O}_{2}$ sensing. Science, 292, 464-468.

13. Auf, G., Jabouille, A., Delugin, M., Guerit, S., Pineau, R., North, S., Platonova, N. et al. (2013). High epiregulin expression in human U87 glioma cells relies on IRE1alpha and promotes autocrine growth through EGF receptor. BMC Cancer, 13, 597.

14. Drummond, G.S., Baum, J., Greenberg, M., Lewis, D., \& Abraham, N.G. (2019). HO-1 overexpression and underexpression: Clinical implications. Arch. Biochem. Biophys., 673, 108073.

15. Hotamisligil, G.S. (2008). Inflammation and endoplasmic reticulum stress in obesity and diabetes. Int. J. Obes. (Lond). 32 (7), S52-S54.

16. Cockman, M.E., Masson, N., Mole, D.R., Jaakkola, P., Chang, G.W., Clifford, S.C., Maher, E.R., et al. (2000). Hypoxia inducible factor-alpha binding and ubiquitylation by the von Hippel-Lindau tumor suppressor protein. J. Biol. Chem., 275, 25733-25741.

17. Minchenko, A.G., Leshchinsky, I., Opentanova, I., Sang, N., Srinivas, V., Armstead, V.E., Caro, J. (2002). Hypoxia-inducible factor-1-mediated expression of the 6-phosphofructo-2-kinase/fructose-2,6-bisphosphatase-3 (PFKFB3) gene. Its possible role in the Warburg effect. J. Biol. Chem., 277, 6183-6187.

18. Minchenko, A., Bauer, T., Salceda, S., Caro, J. (1994). Hypoxic stimulation of vascular endothelial growth factor expression in vitro and in vivo. Laboratory Invest., 71, 374-379.

19. Minchenko, D.O., Danilovskyi, S.V., Kryvdiuk, I.V., Bakalets, T.V., Lypova, N.M., Karbovskyi, L.L., Minchenko, O.H. (2014). Inhibition of ERN1 modifies the hypoxic regulation of the expression of TP53-related genes in U87 glioma cells. Endoplasm. Reticul. Stress Dis., 1, 18-26. 20. Logue, S.E., McGrath, E.P., Cleary, P., Greene, S., Mnich, K., Almanza, A., Chevet, E., et al. (2018). Inhibition of IRE1 RNase activity modulates the tumor cell secretome and enhances response to chemotherapy. Nat. Commun., 9 (1), 3267.

21. Minchenko, O.H., Tsymbal, D.O., Moenner, M., Minchenko, D.O., Kovalevska, O.V., \& Lypova, N.M. (2015). Inhibition of the endoribonuclease of ERN1 signaling enzyme affects the expression of proliferation-related genes in U87 glioma cells. Endoplasm. Reticul. Stress Dis., 2 (1), 18-29.

22. Moenner, M., Pluquet, O., Bouchecareilh, M., \& Chevet, E. (2007). Integrated endoplasmic reticulum stress responses in cancer. Cancer Res., 67, 10631-10634.

23. Lee, J., \& Ozcan, U. (2014). Unfolded protein response signaling and metabolic diseases. J. Biol. Chem., 289, 1203-1211.

24. Maurel, M., \& Chevet, E. (2013). Endoplasmic reticulum stress signaling: the microRNA connection. Am. J. Physiol. Cell. Physiol., 304, C1117-C1126.

25. McMahon, M., Samali, A., \& Chevet, E. (2017). Regulation of the unfolded protein response by noncoding RNA. Am. J. Physiol. Cell. Physiol., 313, C243-C254.

26. Minchenko, D.O. (2015). Dominant-negative constructs of inositol requiring enzyme-1alpha as an effective way to suppression of tumor growth through the inhibition of cell proliferation and angiogenesis and activation of apoptosis. J. Mod. Med. Chem., 3 (1), 35-43.

27. Minchenko, O.H., Tsymbal, D.O., \& Minchenko, D.O. (2015). IRE-1alpha signaling as a key target for suppression of tumor growth. Single Cell Biology, 4(3), 118.

28. Chen, Y.C., Colvin, E.S., Maier, B.F., Mirmira, R.G., \& Fueger, P.T. (2013). Mitogen-inducible gene 6 triggers apoptosis and exacerbates ER stress-induced $\beta$-cell death. Mol.. Endocrinol., 27, 162-171.

29. Minchenko, O.H., Kubaichuk, K.I., Minchenko, D.O., Kovalevska, O.V., Kulinich, A.O., \& Lypova, N.M. (2014). Molecular mechanisms of ERN1-mediated angiogenesis. Int. J. Physiol. Pathophysiol., 5 (1), 1-22.

30. Bochkov, V.N., Philippova, M., Oskolkova, O., Kadl, A., Furnkranz, A., Karabeg, E., Breuss, J., et al. (2006). Oxidized phospholipids stimulate angiogenesis via induction of VEGF, IL-8, COX-2 and ADAMTS-1 metal- 
loprotease, implicating a novel role for lipid oxidation in progression and destabilization of atherosclerotic lesions. Circ. Res., 99 (8), 900-908.

31. Papaioannou, A., Chevet, E. (2018). Driving cancer tumorigenesis and metastasis through UPR signaling. Curr. Top. Microbiol. Immunol., 414, 159-192.

32. Pluquet, O., Dejeans, N., \& Chevet, E. (2014). Watching the clock: endoplasmic reticulum-mediated control of circadian rhythms in cancer. Ann. Med., 46 (4), 233-243.

33. Orelle, C., Carlson, E.D., Szal, T., Florin, T., Jewett, M.C., \& Mankin, A.S. (2015). Protein synthesis by ribosomes with tethered subunits. Nature, 6, 524, 119-124.

34. Reid, D.W., \& Nicchitta, C.V. (2015). Diversity and selectivity in mRNA translation on the endoplasmic reticulum. Nature Reviews Molecular Cell Biology, 16, 221-231.

35. Khameneh, B., Iranshahy, M., Soheili, V., \& Fazly Bazzaz, B.S. (2019). Review on plant antimicrobials: a mechanistic viewpoint. Antimicrob. Resist. Infect. Control, 8, 118.

36. Scheuner, D., \& Kaufman, R.J. (2008). The unfolded protein response: a pathway that links insulin demand with beta-cell failure and diabetes. Endocr. Rev., 29, 317-333.

37. Salvadó, L., Palomer, X., Barroso, E., \& Vázquez-Carrera, M. (2015). Targeting endoplasmic reticulum stress in insulin resistance. Trends Endocrinol. Metab., 26, 438-448. 38. Maxwell, P.H., Wiesener, M.S., Chang, G.W., Clifford, S.C., Vaux, E.C., Cockman, M.E., Wykoff, C.C., et. al. (1999). The tumour suppressor protein VHL targets hypoxia-inducible factors for oxygen-dependent proteolysis. Nature, 399, 271-275.

39. Iliopoulos, O., Kibel, A., Gray, S., \& Kaelin, W.G. Jr. (1995). Tumour suppression by the human von HippelLindau gene product. Nat. Med., 1, 822-826.

40. Ohh, M., Park, C.W., Ivan, M., Hoffman, M.A., Kim, T.Y., Huang, L.E., Pavletich, N., et al. (2000). Ubiquitination of hypoxia-inducible factor requires direct binding to the beta-domain of the von Hippel-Lindau protein. Nat. Cell Biol., 2, 423-427.

41. Uechi, T., Tanaka, T., \& Kenmochi, N. (2001). A complete map of the human ribosomal protein genes: assignment of 80 genes to the cytogenetic map and implications for human disorders. Genomics, 72, 223-230.

42. Wang, G.L., \& Semenza, G.L. (1993). General involvement of hypoxia-inducible factor 1 in transcriptional response to hypoxia. Proc. Natl. Acad. Sci. U. S. A., 90, 4304-4308. 